Proceedings of the 2018 International Scientific Conference 'Economic Sciences for Agribusiness and Rural Economy' No 2, Warsaw, 7-8 June 2018, pp. 238-244

\title{
ARE POLAND AND TURKEY RIVALS IN THE EU AGRICULTURAL MARKET?
}

\section{Funda Gencler, Assistant Professor ${ }^{1}$; Berna Turkekul, Associate Professor²; Altay Ugur Gul, Full Professor ${ }^{3}$}

${ }^{1,3}$ School of Tobacco Expertise, Celal Bayar University

${ }^{2}$ Agriculture Faculty, Ege University

\begin{abstract}
Poland and Turkey are one of the largest global producers and particularly exporters of fruits. The export is of great importance to domestic producers of these fruits. This paper attempts to assess Polish and Turkish fruit sectors' competitiveness. For competitive comparison of Poland and Turkey, balance of foreign trade, trade coverage index, share in export and import, specialisation index, relative revealed comparative export advantage index, relative import penetration index, relative trade advantage index were calculated. According to the results, Turkey has shown to have comparative advantage for all periods. In contrast, however, Poland seems to be losing its advantages. Although Poland's competitiveness is diminishing, Poland enjoys free access to EU market.
\end{abstract}

Keywords: Poland, Turkey, competitiveness

JEL codes: Q17, F12

\section{INTRODUCTION}

The accession to European Union (EU) in 2004 resulted many kinds of agro-trade possibilities and difficulties for Poland. The elimination of customs and other trade barriers led to an increased trade. The free flow of goods on the common international market was set and enhanced, and enabled trade expansions following the integration. The countries which integrated after the enlargement in 2004 had very different conditions concerning the role of agriculture in national economy: its level, volume of agricultural subsidies, production efficiency and competitiveness of the sector. On the other hand Turkey's agricultural structure shows similarities with Poland in terms of population and some other agricultural indicators. Turkey's relations with the EU began in 1964. The Union consists of a large portion of agricultural legislation and due to the excess of the budget allocated to agriculture; Turkey is forced to comply with most of the CAP, like all other candidate countries. The agri-food sector is a major component of the Polish economy, agricultural products export is $12.7 \%$ in total export, accounting for $10.5 \%$ of employment and $2.41 \%$ GDP in 2014 (Eurostat, 2018). These figures for Turkey are $19.5 \%$ employment rate, $7.1 \%$ GDP

\footnotetext{
${ }^{1}$ Corresponding author: 45210 Akhisar, Manisa, Turkey, funda.gencler@cbu.edu.tr, +90 5362372106

${ }^{2}$ Corresponding author: Bölümü 35100 Bornova Izmir, Turkey, bturkekul@gmail.com, +90 232881268

${ }^{3}$ Corresponding author: 45210 Akhisar, Manisa, Turkey, altay.gul@cbu.edu.tr, +90 2364126896
} 
and agricultural products export is $13.9 \%$ in total export in 2015 (TUIK, 2018). Relative changes in competitiveness compared to international markets and EU members will have an effect on the development of agriculture in both countries. If the Polish and Turkish agricultural sectors want to develop and positively contribute to economic growth it must be competitive in the EU market. The sector's competitiveness derives from the mechanisms of comparative advantage.

The competitiveness of a product in the international market depends on the principle of comparative advantages associated with favourable natural factors and lower relative costs of production. It also depends on infrastructure, transport and marketing costs to the end destination. Moreover, its price competitiveness in foreign markets is also influenced by movements in the exchange rate. Finally, competitiveness is also affected by other factors such as product quality, the degree of product differentiation, the seasonality of production and market and government policies of both the exporting country and importing country. The increased competitiveness of a product in the international market is expressed in higher export growth and increased market share. There are many indices of competitiveness in literature. Therefore the purpose of this study is to determine the Poland's and Turkey's competitiveness in the EU market in fruits after Poland accession to the EU. Polish foreign trade in fruit recorded a dynamic growth in volume, and particularly, in the value. The export of fruits from Poland increased from USD 401,008,703 in 2004 to USD 775,995,764 2017. For Turkey the value of fruit export has increased from USD 1,304,747,366 to USD 1,918,095,483 for the same period. For both countries the EU is the major trade partner in fruits.

\section{THEORETICAL BACKGROUND}

Economic approaches to assess competitiveness differ greatly, and depend on analyses related to firms, sectors and overall economy (Frohberg and Hartmann, 1997). Approaches analysing the sector level consider competitiveness to be the ability of an industry to maintain market share, and to compete with foreign counterparts in foreign and domestic markets under free trade conditions (Kim and Marion, 1997). As theoretical reference, competitiveness is mainly linked to comparative advantage, which is connected to the Heckscher-Ohlin theory. An analysis of competitiveness at the sector level is usually carried out by assessing trade indices (Carraresi and Banterle, 2008). Indices approach to competitiveness analysis has been used widely to determine and analyse the competitiveness and the factors influencing the competitiveness (Bender and Li, 2002; Sassi, 2003; Hambalková, 2006; Rusali and Gavrilescu, 2008).

Studies on Turkish economy are mostly sectoral studies. In these studies competitive sectors are determined according to factors of competitiveness in international markets (Akgüngör, Barboros and Kumral, 2002; Y1lmaz, 2003; Ferman, Akgüngör and Yüksel, 2004). Although each study used different models, competitor countries and different products, they offered empirical evidence to show that Turkey gains comparative advantage via relative prices, but cannot sustain its existing competitiveness.

The literature on competitiveness of Polish agriculture, especially in the context of EU entry is very rich. Empirical studies on the competitiveness of Polish agriculture are most frequently based on the concept of comparative advantage. A large number of measures have been used to study revealed comparative advantage. The main ones were carried out by Gorton et al. (2001), Zawalińska (2004), Trajer, Smoliński and Mieczkowski (2014), Wigier (2014), Szczepaniak and Tereszczuk (2016). Overall, the studies on revealed comparative advantage confirmed that Poland has a low comparative advantage in processed products, high comparative advantage in agricultural products.

\section{MATERIALS AND METHODS}

The data set has the exports as well as corresponding imports for the years 2004 through 2017. Each year's data includes, in USD millions values for fruits and agri-food products in Poland, Turkey and the EU. These data is obtained from Comtrade data 
set, compiled and maintained by the United Nations Statistical Office in New York. The data used regarding foreign trade in fruits HS code 08 and agri-food products BEC code 1 .

In order to implement the study objective, the following indices of ex-post competitiveness in foreign trade in fruits have been calculated and analysed for Poland and Turkey.

1. Balance of foreign trade (TB)

$$
T B_{i}=E X_{i f}-I M_{i f} \quad(T B<0 \text { or } T B \geq 0)
$$

where:

$E X_{i f}$ - export of fruits from Poland/Turkey (USD million);

$I M_{i f}$ - import of fruits to Poland/Turkey (USD million).

In terms of the open economy, the positive balance of foreign trade in a given product, continuing for a longer time, may attest to international competitiveness of the country with regard to this product (Trajer, Smoliński and Mieczkowski, 2014).

2. Trade coverage index (TC)

$$
T C_{i}=\frac{E X_{i f}}{I M_{i f}} \quad(T C \geq 0)
$$

where:

$E X_{i f}$ - export of fruits from Poland/Turkey (USD million),

$I M_{i f}$ - import of fruits to Poland/Turkey (USD million).

The value of the TC index greater than 1 means that the country has a relative internal advantage over competitors (Trajer, Smoliński and Mieczkowski, 2014). But also reflects competitiveness revealed in the export dynamics (Trajer, Smoliński and Mieczkowski, 2014).

3. Share in global export (SGE)

$$
S G E_{i}=\frac{E X_{i f}}{E X_{E U f}} \cdot 100 \% \quad(0 \% \leq S G E \leq 100 \%)
$$

where:

$E X_{i f}$ - export of fruit from Poland/Turkey (USD million);

$E_{E U f}-$ the EU export of fruit (USD million).

It is believed that the increasing share in the EU export of a given product means improving of international competitiveness of the country with regard to this product (Trajer, Smoliński and Mieczkowski, 2014), as far as the increase in the value of this index does not result from the increasing re-export only.

4. Specialisation index (SI)

$$
S I_{i}=\frac{E X_{i f}}{E X_{i a}} \div \frac{E X_{E U f}}{E X_{E U a}} \quad(S I \geq 0)
$$

where:

$E X_{i f} \quad-$ export of fruits from Poland/Turkey (USD million);

$E X_{i a} \quad$ - export of agri-food products from Poland/ Turkey (USD million);

$E X_{E U f}-$ EU export of fruits (USD million);

$E X_{E U a}-$ EU export of agri-food products (USD million).

The SI index compares the share of a given product in the agri-food export of the country with the share of this product in the EU agri-food export. The SI index values greater than 1 may be indicative of high competitiveness (Trajer, Smoliński and Mieczkowski, 2014), as long as they are not the result of the large re-export only.

5. Share in global import (SGI)

$$
S G I_{i}=\frac{I M_{i f}}{I M_{E U f}} \cdot 100 \% \quad(0 \% \leq S G I \leq 100 \%)
$$

where:

$I M_{i f} \quad$ - import of fruits to Poland/Turkey (USD million);

$I M_{E U f}-$ EU import of fruits (USD million).

The decreasing share in the EU import of a given product may mean improving of competitiveness 
of the country with regard to this product (Trajer, Smoliński and Mieczkowski, 2014).

6. Relative revealed comparative export advantage index (XRCA)

$$
X R C A_{i}=\frac{E X_{i f}}{E X_{E U f}} \div \frac{E X_{i \neq f}}{E X_{E U \neq f}} \quad(X R C A \geq 0)
$$

where:

$E X_{i f} \quad-$ export of fruits from Poland/Turkey (USD million);

$E X_{E U f}-$ EU export of fruits (USD million);

$E X_{i \neq f}$ - export of agri-food products from Poland/ Turkey excluding fruits (USD million);

$E X_{E U \neq f}-$ EU export of agri-food products excluding fruits (USD million).

7. Relative import penetration index (MRCA)

$$
M R C A_{i}=\frac{I M_{i f}}{I M_{E U f}} \div \frac{I M_{i \neq f}}{I M_{E U \neq f}} \quad(M R C A \geq 0)
$$

where:

$I M_{i f} \quad$ - import of fruits to Poland/Turkey (USD million);

$\mathrm{IM}_{\mathrm{EUf}}-\mathrm{EU}$ import of fruits (USD million);

$I M_{i \neq f}$ - import of agri-food products to Poland/ /Turkey excluding fruits (USD million);

$I M_{E U \neq f}-$ EU import of agri-food products excluding fruits (USD million).

8. Relative trade advantage index (RTA)

$$
R T A_{i}=X R C A_{i}-M R C A_{i} \quad(R T A<0 \text { or } R T A \geq 0)
$$

If the RTA $\mathrm{R}_{\mathrm{i}}$ index is positive and the XRCA index is also greater than 1 , it attests to high competitiveness of the country with regard to a given product when compared to other countries of the EU in total. On the other hand, the negative value of the RTA $\mathrm{A}_{i}$ index and also the value of the MRCA $_{i}$ index greater than 1 means that the country shows the absence of competitiveness. In other cases, the results of the analysis are not unambiguous (Trajer, Smoliński and Mieczkowski, 2014).

\section{RESULTS AND DISCUSSION}

In the analysed period, i.e. in the years 2004-2017, the Polish foreign trade balance (TB) in fruits was negative (Table 1). The value balance decreased from USD 12,529,660 in 2004 to USD -169,104,046 in 2017. The trade balance, negative and worsening in the years 2004-2017, to a very large extent attests to the low and decreasing competitiveness of Poland in the EU trade in fruits.

In the years 2004-2017, the value of the trade coverage index (TC) was characterised by a downward trend. The TC index had the highest value in 2004 and the lowest in 2011. Throughout the analysed period, the TC index was significantly lower than 1, which shows that Poland has a relative internal disadvantage over foreign competitors. The low and decreasing value of the TC index reflects small and diminishing competitiveness of Poland in foreign trade in fruits.

In the years 2004-2017, the share of Poland in the global export of fruits (SGE) showed a downward trend. This index decreased most in 2010-2012 (Table 1). The decrease in the level of the SGE index also means declining of Poland's competitiveness in trade in fruits. In the analysed period, the share of Poland in the global import of fruits (SGI) was at the similar level and did not exceed $4.33 \%$ (Table 1 ). In the analysed period, the level of the specialisation index (SI) showed a downward trend and in 2017 was nearly 3 times lower than 2004. Such value of the SI index confirms low and diminishing competitiveness of Poland in EU trade in fruits.

In the entire analysed period, the relative revealed comparative export advantage index (XRCA) assumed values greater than 1 and also, the relative trade advantage index (RTA) was positive (Table 1). Both indices were characterised by a downward trend and decreased almost three times. Such values of the XRCA and RTA indices confirm low and diminishing competitiveness of Poland in the EU trade in fruits.

On the other hand Turkish trade balance (TB) in fruits was positive and showed an upward trend (Table 2). The value balance increased from USD $1,282,385,892$ in 2004 to USD 1,879,089,768 in 2017. 
Proceedings of the 2018 International Scientific Conference 'Economic Sciences for Agribusiness and Rural Economy' No 2, Warsaw, 7-8 June 2018, pp. 238-244

Table 1. Indices of Poland's competitiveness in the EU trade in fruits

\begin{tabular}{|c|c|c|c|c|c|c|c|c|}
\hline Years & TB & TC & SGE & SGI & SI & XRCA & MRCA & RTA \\
\hline 2004 & 12529660 & 1.03 & 23.31 & 3.09 & 3.07 & 3.27 & 0.76 & 2.52 \\
\hline 2005 & 6356888 & 1.01 & 22.07 & 3.00 & 2.26 & 2.35 & 0.62 & 1.73 \\
\hline 2006 & 33286634 & 1.07 & 20.77 & 3.20 & 1.94 & 2.00 & 0.61 & 1.39 \\
\hline 2007 & -49752176 & 0.93 & 20.70 & 4.03 & 1.72 & 1.77 & 0.64 & 1.13 \\
\hline 2008 & -12117153 & 0.99 & 22.07 & 4.18 & 1.77 & 1.82 & 0.55 & 1.28 \\
\hline 2009 & -112911531 & 0.82 & 15.73 & 3.66 & 1.23 & 1.24 & 0.46 & 0.78 \\
\hline 2010 & -160469974 & 0.76 & 13.30 & 3.89 & 1.09 & 1.09 & 0.48 & 0.62 \\
\hline 2011 & -213525020 & 0.73 & 13.10 & 4.19 & 1.12 & 1.13 & 0.50 & 0.62 \\
\hline 2012 & -117281364 & 0.84 & 12.31 & 4.07 & 1.07 & 1.07 & 0.48 & 0.59 \\
\hline 2013 & -119016904 & 0.86 & 14.57 & 4.33 & 1.08 & 1.09 & 0.45 & 0.64 \\
\hline 2014 & -110192801 & 0.87 & 14.21 & 3.90 & 1.06 & 1.06 & 0.41 & 0.65 \\
\hline 2015 & 37619721 & 1.05 & 20.41 & 3.55 & 1.40 & 1.42 & 0.39 & 1.03 \\
\hline 2016 & -44371307 & 0.94 & 18.03 & 3.41 & 1.29 & 1.30 & 0.37 & 0.93 \\
\hline 2017 & -169104046 & 0.82 & 19.55 & 4.10 & 1.36 & 1.37 & 0.41 & 0.97 \\
\hline
\end{tabular}

Source: own elaboration pursuant to the data from UN.

Table 2. Indices of Turkey's competitiveness in the EU trade in fruits

\begin{tabular}{|l|c|c|c|c|c|c|c|c|}
\hline Years & TB & TC & SGE & SGI & SI & XRCA & MRCA & RTA \\
\hline 2004 & 1282385892 & 58.35 & 75.83 & 0.18 & 14.90 & 25.83 & 0.17 & 25.66 \\
\hline 2005 & 1677278491 & 72.72 & 86.99 & 0.16 & 14.61 & 26.24 & 0.13 & 26.11 \\
\hline 2006 & 1488767193 & 58.80 & 62.10 & 0.17 & 11.67 & 19.01 & 0.16 & 18.85 \\
\hline 2007 & 1604249003 & 44.01 & 53.00 & 0.22 & 10.57 & 16.99 & 0.17 & 16.81 \\
\hline 2008 & 1582145746 & 47.51 & 44.66 & 0.18 & 9.70 & 14.64 & 0.11 & 14.53 \\
\hline 2009 & 1618302291 & 44.58 & 52.13 & 0.22 & 11.04 & 18.39 & 0.15 & 18.24 \\
\hline 2010 & 1811520734 & 46.91 & 49.04 & 0.23 & 10.96 & 18.57 & 0.12 & 18.45 \\
\hline 2011 & 1939559111 & 40.68 & 45.22 & 0.26 & 11.27 & 18.81 & 0.11 & 18.70 \\
\hline 2012 & 1860455828 & 54.81 & 38.40 & 0.19 & 10.30 & 17.05 & 0.10 & 16.95 \\
\hline 2013 & 2020705608 & 70.94 & 39.77 & 0.14 & 10.55 & 17.30 & 0.08 & 17.22 \\
\hline 2014 & 2110753902 & 45.77 & 42.24 & 0.22 & 10.78 & 17.45 & 0.11 & 17.34 \\
\hline 2015 & 2266188975 & 43.68 & 59.15 & 0.25 & 12.71 & 21.13 & 0.11 & 21.03 \\
\hline 2016 & 2078509893 & 63.38 & 54.60 & 0.15 & 12.96 & 21.18 & 0.07 & 21.11 \\
\hline 2017 & 1879089768 & 49.17 & 48.33 & 0.17 & 12.50 & 19.39 & 0.07 & 19.32 \\
\hline
\end{tabular}

Source: own elaboration pursuant to the data from UN. 
Briefly, the trade balance is positive indicating high and increasing competitiveness of Turkey in the EU market. Although TC index fluctuates over time, TC index shows that Turkey has a relative comparative advantage. The large and increasing value of the TC index reflects high and improving competitiveness of Turkey in the EU market in fruits. In the analysed period, the share of the EU in the Turkish import of fruits was $11.69 \%$ compared to Poland's. Therefore SGI index was low confirming the increase in competitiveness of Turkish fruit sector. Similarly the SI index confirms high and improving competitiveness of Turkey in the EU.

In the entire analysed period, the relative revealed comparative export advantage index (XRCA) values were greater than 1 and the relative trade advantage index (RTA) was positive (Table 2). Both values of XRCA and RTA indices show high and improving competitiveness of Turkish fruit sector.

\section{CONCLUSIONS}

An analysis of the competitiveness of Polish and Turkish fruit sector with respect to the EU market has been presented, based on eight indices of comparative advantage, and calculated for the period 2004 to 2017. Indices approach to competitiveness analysis indicated that Turkey has comparative advantage over Poland in the EU market. The Common Organization of Markets limits considerably the regulation and commercial accessibility of this market. The EU preserves a quite elevated competitiveness differential encouraging the intra-communal exchanges. Therefore, Poland enjoys free access to the EU market and the development of the global market, although its competitiveness is declining. The CAP instruments covering Poland resulted in doubling the actual income of farmers, which improved their economic situation and increased the opportunities to finance the current expenditure and to implement modernisation investments. After the accession, a considerable production and economic progress was made, but its competitiveness does not represent a strong foundation of international competitiveness. These difficulties related to physical accessibility limits the position of Turkey.
For Turkey competing in the EU market is possible due to the integration measures consisting in the establishment of producer groups and organisations. The producer organisations and groups make it possible for the Turkish farmers to consolidate the supply, prepare standardised product batches and with base storage provide the supply throughout the season.

\section{REFERENCES}

1. Akgüngör, S., Barboros, R.F., Kumral, N. (2002). Competitiveness of the Turkish Fruit and Vegetable Industry in the European Market. Russian and East European Finance and Trade, 38, pp. 34-53.

2. Bender, S., Li, K.W. (2002). The Gain and Loss of Comaparative Advantage in Manufactured Export Among Regions, Discussion Paper 853. Economic Growth Center, Yale University, New Haven, CT.

3. Carraresi, L., Banterle, A. (2008). Measuring competitiveness in the EU market: a comparison between food industry and agriculture. In: Proceedings of 12th Congress of the European Association of Agricultural Economics, Ghent.

4. Eurostat (2018). Statistical Factsheet - Poland. Retrieved from: https://ec.europa.eu/agriculture/sites/ agriculture/files/statistics/factsheets/pdf/pl_en.pdf [Accessed 29.05.2018].

5. Ferman, M., Akgüngör, S., Yüksel, A.H. (2004). The Competitiveness of Turkey and Its Sustainability: A comparison in the EU Market from the Perspectives of the Rival Countries and Turkey [in Turkish]. In: Proceedings of Economy Congress of Turkey, İzmir, 05-09.05.2004, pp. 4-29.

6. Frohberg, K., Hartmann, M. (1997). Comparing Measures of Competitiveness. IAMO Discussion Paper 2.

7. Gorton, M., Danilowska, A., Jarka, S., Straszewski, S., Zawojska, A., Majewski, E. (2001). The International Competitiveness of Polish Agriculture. EU Phare project P9704-01-03/04/13/17. Ministerwo Rolnictwa Rozwoju Wsi, Warszawa.

8. Hambalková, M. (2006). The factors of competitiveness and the quantification of their impact on the export efficiency of grape and wine in the Slovak Republic. AGRIC-ECON- CZECH, 52, pp. 389-394.

9. Kim, D., Marion, B.W. (1997). Domestic Market Structure and Performance in Global Markets: Theory and Empirical Evidence from U.S. Food Manufacturing Industries. Review of Industrial Organization, 12, pp. 335-354. 
10. Rusali, M., Gavrilescu, C. (2008). Competitive advantage and Disadvantages in Romania's Agri-Food Trade - Trends and Challenges. In: Proceedings of 12th Congress of the European Association of Agricultural Economics, Ghent.

11. Sassi, M. (2003). The Competitiveness of Agricultural Products in World Trade and the Role of the European Union. In: International Conference 'Agricultural Policy Reform and the WTO: where are We heading?", Capri, 7, pp. 23-26.

12. Szczepaniak, I., Tereszczuk, M. (2016). The improvement in the international competitiveness of the Polish food sector and its support with public funds during Poland's membership in the EU. Rivista di Economia Agraria, 71 (1) [Suppl.], pp. 134-142.

13. Trajer, M., Smoliński, P., Mieczkowski, M. (2014). Poland's competitiveness in foreign trade in apples. Scientific Journal Warsaw University of Life Sciences - SGGW. Problems of World Agriculture, 14 (29), 4, pp. 178-187.
14. TUIK (2018). Tarımsal Fiyat ve Ekonomik Hesaplar [Agricultural Price and Economic Accounts]. Retrieved from: http://www.tuik.gov.tr/PreTablo.do?alt_id=1004 [Accessed 20.05.2018].

15. United Nations (2018). Yearbook of International Trade Statistics. United Nations, New York.

16. Wigier, M. (2014). The Competitiveness of Polish Agriculture after Accession to the EU. Economics of Agriculture, 61 (1), pp. 87-102.

17. Yllmaz, B. (2003). Turkey's Competitiveness in the European Union: A Comparison with Five Candidate Countries - Bulgaria, The Czech Republic, Hungary, Poland, Romania - and the EU15. Ezoneplus Working Paper 12, Berlin.

18. Zawalińska, K. (2004). The Competitiveness of Polish Agriculture in the Context of Integration with the European Union [PhD thesis]. Wydawnictwo Uniwersytetu Warszawskiego, Warszawa. 